\title{
HUBUNGAN GAYA KEPEMIMPINAN DAN KINERJA DENGAN ETOS KERJA GURU SEKOLAH DASAR DI KOTA PADANG PANJANG
}

\author{
Hubban Jamma \\ Guru Agama SD Silaing Atas Padangpanjang, \\ Koresponden: J I. Cokrominoto No.224 Rt.3 Silaing Atas Kecamatan Padangpanjang Barat \\ e-mail.hbbnjmm@gmail.com
}

wares

\begin{abstract}
Relations Leadership Style and Performance with the Work Ethic Teachers in Primary School Kota Padangpanjang. The purpose of this research was to reveal how extend the correlations of principal leadership, teachers' work satisfaction with teachers' work ethic at elementary schools in Padang Panjang Regency.

This research revealed: (1) Style of Principal leadership correlated with teachers' work ethic significantly. The extended of correlation of teachers work ethic was determined by style of principal leadership as $27,1 \%$. (2) Teachers work satisfaction correlated with teachers' work ethic significantly. Teachers' work ethic was determined by teachers work satisfaction as $26,2 \%$. (3) The style of principal leadership and teachers work satisfaction (X2) correlated significantly with teachers' work ethic at elementary schools in Padang Panjang Regency, and the extend teachers' work ethic was determined by style of principal eldership and teachers' work satisfaction as 39,5\%.
\end{abstract}

Kata kunci: Gaya kepemimpinan, kepuasan kerja, etos kerja

\section{PENDAHULUAN}

Sekolah Dasar (SD) merupakan jenjang pendidikan terendah yang tujuannya adalah untuk memberikan bekal kemampuan dasar yang diperlukan, juga berperan mempersiapkan siswa agar dapat melanjutkan pendidikan ke jenjang persekolahan berikutnya. Perwujudan tujuan sekolah tersebut ditentukan oleh beberapa faktor, antara lain faktor guru dan kepala sekolah.

Guru harus benar-benar mengerti dan menyadari tugasnya, sebab terlaksana atau tidaknya pengajaran di sekolah atau keberhasilannya sangat ditentukan oleh usaha atau kegiatan guru. Salah satu tugas guru adalah tugas pensucian dan pengajaran, hal ini diisyaratkan oleh Allah SWT, bahwa tugas pokok Rasulullah adalah mengajarkan Al-kitab dan Al-Hikmah kepada manusia serta mensucikan mereka, yakni mengembangkan dan membersihkan jiwa mereka. Sebagaimana Allah SWT, menyebutkannya dalam Al-Qur'an surat Al-Baqarah ayat 129 : 
"Ya Tuhan kami, utuslah untuk mereka seorang rasul dari kalangan mereka yang akan membacakan kepada mereka ayat-ayat engkau dan mengajarkan kepada mereka Al-Kitab an Al-Hikmah serta mensucikan mereka. Sesungguhnya Engkaulah Yang Maha Perkasa lagi Maha bijaksana?.

Ayat ini menerangkan bahwa sebagai seorang pendidik yang agung, beliau tidak hanya mengajarkan ilmu, tapi lebih dari itu, dimana ia juga mengemban tugas untuk memelihara kesucian manusia. Untuk itu guru sebagai pendidik juga harus memiliki tanggung jawab untuk mempertahankan kesucian atau fitrah anak didiknya sebagaimana yang telah diajarkan oleh Rasulullah SAW.

Berdasarkan Firman Allah SWT di atas, Al-Nahlawi (1995:170) menyimpulkan bahwa tugas pokok (peran utama) guru dalam pendidikan Islam adalah sebagai berikut :

1. Tugas pensucian. Guru hendaknya mengembangkan dan membersihkan jiwa peserta didik agar dapat mendekatkan diri kepada Allah serta menjauhkannya dari keburukan dan menjaganya agar tetap berada pada fitrahnya.

2. Tugas pengajaran. Guru hendaknya menyampaikan beberapa pengetahuan dan pengalaman kepada peserta didik untuk diterjemahkan dalam tingkah laku dan kehidupannya.
Oleh karena itu guru dituntut agar punya pengetahuan, keterampilan, pengalaman dan juga kebebasan mengelola pengajaran. Di lingkungan sekolah, guru bertugas sebagai pengajar dan pendidik. Sebagai pengajar, guru memberikan pengetahuan (kognitif), sikap dan nilai (afektif), dan keterampilan (psikomotorik). Guru memiliki tugas dan tanggung jawab moral yang besar terhadap keberhasilan anak didik.

Satu hal lagi yang perlu diingat, bahwa kepala sekolah pada dasarnya adalah guru yang mendapat tugas tambahan sebagai pemimpin unit kerja. Oleh sebab itu mereka masih dibebani tugas-tugas mengajar di depan kelas yang sifatnya wajib.

Pemimpin memegang peranan yang sangat penting untuk menggerakan bawahannya dalam rangka mencapai tujuan organisasi. Kepemimpinan kepala sekolah harus mampu mempengaruhi bawahan agar dapat melaksanakan tugasnya dengan baik, pemimpin juga harus bisa dekat dengan bawahannya,agar bawahannya merasa tenang menerima bimbingan dan arahan oleh atasannya, hal ini sesuai dengan firman Allah dalam surat Shad ayat 26 yang berbunyi :

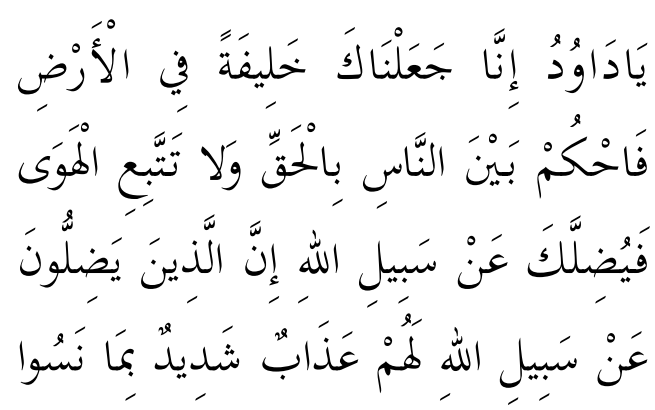




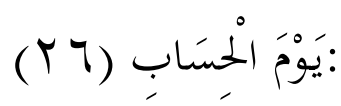

"Hai Daud, sesunggubnya Kami menjadikan kamu khalifah (penguasa) di muka bumi, maka berilah keputusan (perkara) di antara manusia dengan adil dan janganlah kamu mengikuti hawa nafsu, karena ia akan menyesatkan kamu dari jalan Allah SWT. Sesungguhnya orangorang yang sesat dari jalan Allah SWT akan mendapat azab yang berat, karena mereka melupakan hari perhitungan."

(Qs Shad: 26)

Oleh karena itu salah satu peran dari pemimpin adalah menerapkan gaya kepemimpinan yang efektif agar tujuan organisasi dapat dicapai sesuai dengan rencana. Gaya kepemimpinan disini dapat ditinjau dari dua sisi, yaitu gaya kepemimimpinan kepala sekolah yang berorientasi pada tugas dan gaya kepemimpinan yang berorientasi kepada bawahan.

Untuk dapat melaksanakan kepemimpinan yang baik, dan tugastugasnya serta dapat memainkan peranannya demi keberhasilan sekolah yang dipimpinnya maka ia perlu memiliki kemampuan yang memadai. Karena kepala sekolah merupakan pemegang kunci dari keberhasilan sekolah.

Keberhasilan kepala sekolah dalam memimpin anak buahnya akan berdampak kepada etos kerja guru bawahannya dan juga sebaliknya, etos kerja guru bawahannya akan timbul apabila ia mampu memberikan ransangan terhadap etos kerja guru bawahannya. Dan apabila etos kerja guru sudah timbul, maka etos kerja gurunya akan mempengaruhi akan keberhasilan sekolah.

Pengaruh etos kerja guru terhadap proses tindakan kerja dipandang sangat kuat, karena etos kerja gurulah yang mengarahkan potensi rohani serta fisik badani terhadap proses tindakan kerja kepala sekolah. Etos kerja guru pulalah yang mampu melahirkan kesadaran, kecintaan, dan tanggung jawab terhadap tugas kerja.

Guru dituntut untuk bekerja dengan memberikan pelayanan sebaik-baiknya kepada pemakai sekolah seperti siswa, orang tua, dan masyarakat. Salah satu faktor yang menunjang guru untuk bekerja dengan baik yaitu kepuasan kerja. Artinya jika guru puas terhadap perlakuan organisasi (sekolah) maka mereka akan bekerja penuh semangat dan bertanggug jawab.

Kepuasan kerja (job statisfaction) guru merupakan sasaran penting dalam manajemen sumber daya manusia, karena secara langsung maupun tidak langsung akan mempengaruhi produktivitas kerja. Suatu gejala yang dapat mengganggu pencapaian tujuan organisasi sekolah rendahnya kepuasan kerja guru dimana timbul gejala seperti kemangkiran, malas bekerja, banyaknya keluhan guru, rendahnya prestasi kerja, rendahnya kualitas prestasi kerja, rendahnya kualitas pengajaran, indisipliner guru, dan gejala negatif lainnya.

Dalam usaha peningkatan produktivitas kerja, guru yang membantu tercapainya tujuan lembaga perlu memperoleh kepuasan 
dalam bekerja. Hal ini dapat menciptakan kegairahan, ketekunan inisiatif, dan kreativitas kerja yang pada akhirnya diharapkan dapat menghasilkan produktivitas kerja yang tinggi pula. Sebaliknya, jika seorang guru tidak merasakan kepuasan dalam bekerja, maka keadan ini diperkirakan akan menimbulkan hal-hal yang merugikan lembaga. Jadi, masalah kepuasan kerja guru perlu mendapat perhatian yang serius dari kepala sekolah mereka.

Pelayanan guru yang kurang baik perlu ditangani agar hasil belajar siswa dapat ditingkatkan. Hal ini merupakan masalah penting yang sampai sekarang belum banyak diteliti dan belum banyak ditangani secara baik. Oleh karena itu masalah kepuasan kerja guru menarik untuk diteliti secara ilmiah dalam rangka menemukan beberapa hal yang dapat dijadikan sebagai solusi dari pemecahan masalah yang terdapat sekarang.

Etos kerja guru dapat berarti ciri-ciri atau sifat (karakteristik) mengenai cara bekerja, yang sekaligus mengandung makna kualitas esensialnya, sikap dan kebiasaannya serta pandangannya terhadap kerja yang dimiliki oleh guru dalam melaksanakan dan mengembangkan kegiatan pendidikan di sekolah.

Pada dasarnya, Islam adalah agama atau kerja (praksis).Inti ajarannya adalah bahwa hamba mendekati dan memperoleh ridha Allah melalui kerja atau amal saleh dan dengan memurnikan sikap penyembahan hanya kepada-Nya. Firman Allah dalam surah Al-Kahfi: 110

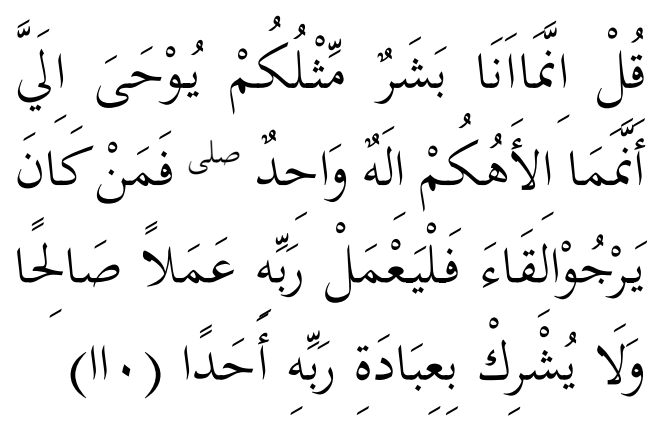

"Katakanlah: Sesungguhnya Aku Ini manusia biasa seperti kamu, yang diwahyukan kepadaku: "Bahwa Sesungguhnya Tuhan kamu itu adalah Tuhan yang Esa". barangsiapa mengharap perjumpaan dengan Tuhannya, Maka hendaklah ia mengerjakan amal yang saleh dan janganlah ia mempersekutukan seorangpun dalam beribadat kepada Tuhannya". (Q.s. Al-Kahfi: 110)

Dengan ayat diatas tersebut mengandung makna bahwa Islam adalah agama yang mengajarkan "orientasi kerja" (achievement rientation), sebagaimana juga dinyatakan dalam ungkapan Nurcholis Majid (1995: 217 ) bahwa "penghargaan dalam jahiliyah berdasarkan keturunan, sedangkan penghargaan dalam islam berdasarkan amal". Tinggi atau rendahnya derajat takwa seseorang juga sangat ditentukan oleh prestasi kerja atau kualitas amal saleh sebagai aktualisasi dari potensi imannya.

Nilai-nilai mendasar yang terkandung dalam ajaran islam tersebut menggaris bawahi suatu totalitas pandangan muslim yang seharusnya lebih menghargai dan concern terhadap kualitas proses dan produk 
kerja ketimbang bersikap dan bekerja apa adanya untuk sekedar melaksanakan tugas dan kewajiban yang bersifat rutinitas. Nilainilai tersebut sekaligus harus menjadi inspirasi kekuatan, pendorong bagi berbagai gerakan umat islam, termasuk didalamnya yang berkaitan dengan gerakan ilmiyah dan atau gerakan peningkatan dan pengembangan kualitas pendidikan islam di sekolah.

Namun demikian, agaknya nilai-nilai mendasar tersebut belum tentu senantiasa menjadi kesadaran setiap muslim dan terefleksi dalam realitas kehidupannya, sungguhpun (kadangkala) ia di kenal sebagai muslim yang memiliki kesalehan ritual dikalangan masyarakatnya. Bangsa Indonisia yang mayoritas beragama islam sepatutnya merasa perihatin ketika membaca dan menyimak statement Amin Rais, sebagaimana telah dimuat dalan Jawa Pos, yang mengemukakan hasil penelitian dari World Bank bahwa dari sekitar empat puluh lima bangsa di dunia ternyata bangsa Indonesia tidak termasuk yang paling rajin. Tetapi dari yang paling malas, ternyata bangsa Indonesia menduduki rangking ke tiga dari 45 bangsa itu. Senada dengan itu A. Mukti ali (1987: 170) Hal ini merupakan salah satu indikasi akan lemahnya etos kerja guru bangsa Indonesia.

Menurut Bukhori Mokhtar (1994:41) Keadaan etos kerja guru seseorang setidak-tidaknya dapat dididik dari cara kerjanya yang memiliki 3 dari dasar, yaitu (1) keinginan untuk menjunjung tingi mutu pekerjaan (job quality); (2) menjaga harga diri dalam melaksanakan pekerjaan; dan (3) keinginan untuk memberikan layanan kepada masyarakat melalui karya profesionalnya.

Ketiga ciri dasar tersebut pada dasarnya terkait dengan kualifikasi yang harus dimiliki oleh guru pada umumnya, yaitu kualifikasi personal dan profesional. Ciri yang pertama terkait dengan kualifikasi personal, sedangkan ciri kedua dan ketiga terkait dengan kualifikasi personal dan sosial.

Dalam pola pemahaman sistem tenaga kependidikan di Indonesia, menurut Zaini Sjahminan (1983:36) terdapat tiga dimensi umum kompetensi yang saling menunjang membentuk kompetensi profesional tenaga kependidikan, yaitu (1) kompetensi personal; (2) kometensi sosial; dan (3) kompetensi profesional.

Peran dan tangung jawab guru dalam proses pendidikan sangat erat. Apalagi dalam konteks pendidikan dalam islam, dimana semua aspek kependidikan dalam islam terkait dengan nilai-nilai (value bound), yang melihat guru bukan saja pada penguasaan material-pengethuan, tetapi juga pada investasi nilai-nilai moral dan spiritual yang diembannya untuk ditranspormasikan ke arah pembentukan kepribadian anak didik. Sebagai komponen paling pokok dalam pendidikan Islam, guru dituntut bagaimana membimbing, melatih, dan membiasakan anak didik berperilaku yang baik. Karena itu, eksistensi guru tidak saja mengajarkan 
tetapi sekaligus mempraktikkan ajaranajaran dan nilai-nilai pendidikan islam.

Begitu muliyanya posisi guru dalam pendidikan Islam, $A l$ - Zurnuji dalam kitabnya Ta'lim al-Muta'alim Thariqah alTảallum mengingatkan bahwa anak didik (thalib al-ilm) tidak akan memperoleh ilmu dan tidak akan mendapatkan manfaat dari ilmu itu kecuali menghargai ilmu dan orang yang berilmu, serta menaruh hormat kepada guru. Sehingga Al-Zurnuji mengingatkan anak didik untuk tidak memilih mata pelajaran kecuali atas izin guru. Berkaitan dengan kemuliaan guru dalam mengajar dan mendidik, penyair Muslim terkenal Ahmad Syauqi mengidentifikasi laksana rasul bagi kaumnya. Sebagaimana dilukiskan dalam syairnya "Qum li al-Mu'allim wa Qibi al-Tabjila, Kada al-Mu'allim 'an Yakuna Rasula" (Berdirlah kamu disaat kamu datang dan jagalah kehormatannya karena eksistensi guru itu nyaris laksana rasul bagi umatnya).

Al-Gazali (1967:116) mengatakan Guru adalah pribadi yang menyuguhkan makanan kejiwaan (taqziyah al-nafs), membenahi dan membangun akhlak (tahdzib al-akblaq wataqwimuha) bagi anak didik, dan mengantarkan mereka kearah kehormatan hidup.

Beberapa penelitian terdahulu telah membuktikan bahwa terdapat hubungan yang positif antara Gaya Kepemimpinan, Kepuasan Kerja dengan Etos Kerja. Ike Kusdiyah Rachmawati, penelitiannya tentang hubungan Gaya Kepemimpinan,
Kepuasan Kerja dengan Etos Kerja di SMPN 48 Palembang Sumatera Selatan penelitian kuantitatif deskriptif . Hasil penelitiannya disimpulkan bahwa $42 \%$ Gaya Kepemimpinan, Kepuasan Kerja berhubungan dengan Etos Kerja Guru . Selanjutnya penelitian yang terkait juga adalah penelitian yang dilakukan oleh Irsan, yaitu Etos kerja guru, suatu studi pada guru-guru SMP Negeri Medan. Dalam kesimpulan dia menyimpulkan bahwa kepuasan kerja secara positif dan berarti berhubunganterhadap etos kerja guru sebesar $34 \%$. Seterusnya penelitian yang dilakukan oleh Oktafiani, yaitu penelitian yang berjudul hubungan Gaya Kepemimpinan Kepala Sekolah dengan Etos kerja guru Di MAN Cibinong tahun 2011, suatu penelitian korelasional antara Gaya Kepemimpinan Kepala Sekolah dengan Etos kerja guru Di MAN , dalam penelitiannya ini dia menyimpulkan bahwa sebanyak 34,57 \% Gaya Kepemimpinan Kepala Sekolah dengan Etos kerja guru Di MAN Cibinong.

Oleh sebab itu penulis telah melakukan penelitian yang berjudul" Hubungan Gaya Kepemimpinan Kepala Sekolah dan Kepuasan Kerja guru dengan Etos kerja guru SD Negeri di Padang Panjang”.

Diharapkan, Penelitian ini bermanfaat untuk pengembangan manajemen pendidikan, khususnya Etos kerja guru,selanjutnya Guru SDN Kota Padang Panjang dalam rangka meningkatkan kepuasan mereka dalam mengajar, Kepala 
SDN Kota Padang Panjang agar lebih memperlihatkan gaya kepemimpinan yang disenangi guru, meningkatkan etos kerja guru dan kepuasan kerja guru SDN yang menjadi bawahannya sehingga dapat menghasilkan guru yang berkualitas, Komite sekolah agar bisa mendorong kepala sekolah untuk terus memperhatikan kualiatas kepemimpinannya, Pengawas tingkat TK dan SD menjadi acuan dalam mengawasi kepala sekolah dan guru dibawah binaannya, Kadisdik Padang Panjang agar selalu berupaya untuk memberikan berbagai pelatihan tentang kepemimpinan kepala sekolah dan seminar-seminar tentang kepuasan kerja,agar etos kerja guru di Padang Panjang dapat ditingkatkan.

\section{METODOLOGI PENELITIAN}

Jenis Penelitian ini adalah penelitian Korelasional, yaitu penelitian yang ingin mengetahui hubungan antara variabel tertentu, dalam penelitian ini terdapat variabel terikat yaitu etos kerja guru ( Y ) dan dua variabel bebas yaitu Gaya kepemimpinan ( X 1 ) dan Kepuasan kerja ( X 2 ). Penelitian ini menggunakan metode deskriptif kuantitatif karena peneliti ingin menggambarkan kondisi lapangan secara apa adanya dengan melihat berbagai masalah yang timbul saat ini. Dengan demikian, peneliti mengharapkan dapat memberikan alternatif pemecahanya sehingga memberikan suatu informasi yang berguna bagi obyek penelitian dengan populasi seluruh guru-guru SDN Kota Padang Panjang yang berjumlah 355orang yang berasal dari 33 SD Negeri di Padang Panjang terdiri dari 65 orang laki-laki dan 290 orang perempuan, Dalam penelitian ini sampel diambil dengan menggunakan teknik menurut Cochran , stratified proportional random sampling, dengan jumlah sampel 75 orang.

Pengumpulan data pada penelitian ini dilakukan dengan cara menemui para responden secara langsung dan angket dijawab oleh responden diluar jam kerja agar tidak mengganggu proses pembelajaran, selain itu angket tidak boleh dibawa pulang, hal ini bertujuan agar data yang diperoleh dapat diakui keabsahan dan keakuratannya.

Instrumen yang digunakan untuk mengumpulkan data dari ketiga variabel dalam penelitian ini adalah 87 item soal angket yang berasal dari 102 soal yang telah di ujicobakan. Soal menggunakan model Skala Likert dengan lima alternatif jawaban. Yaitu selalu (SL), sering (SR), ragu (R), jarang (JR) dan tidak pernah (TP). Sesuai dengan sifat kosioner, maka butir pernyataan postif diberi skor $\mathrm{SL} / \mathrm{SP}=5, \mathrm{SR} / \mathrm{P}=4, \mathrm{R} /$ $\mathrm{R}=3, \mathrm{JR} / \mathrm{TP}=2, \mathrm{TP} / \mathrm{STP}=1$. sedangkan pernyataan negatif diberi skor $\mathrm{SL} / \mathrm{SP}=1, \mathrm{SR}$ $/ \mathrm{P}=4, \mathrm{R} / \mathrm{R}=3, \mathrm{JR} / \mathrm{TP}=4, \mathrm{TP} / \mathrm{STP}=5$.

Hipotesis yang diajukan, diuji dengan regresi linier dan regresi berganda, dan sesuai dengan persyaratan penggunaan uji ini, maka terlebih dahulu dilakukan uji normalitas, uji linieritas dan uji homogenitas. 


\section{PEMBAHASAN}

Berdasarkan hasil analisis deskripsi data dan tingkat pencapaian responden guru-guru SD Negeri di Padang Panjang terhadap setiap variabel yang diukur, maka peneliti menemukan hasil penelitian dimana tingkat pencapaian responden tentang Etos kerja guru ternyata cukup (67,23\%), Gaya Kepemimpinan kepala sekolah SD Negeri di Padang Panjang ternyata kurang baik (60,92 $\%$ ), dan Kepuasan kerja guru ternyata kurang baik ( 63,72\%).

Temuan ini ternyata tidak berbeda dan dugaan awal yang berdasarkan pengamatan pra survei yang menyatakan bahwa Etos kerja guru, Gaya kepemimpinan kepala sekolah dan Kepuasan kerja guru SD Negeri di Padang Panjang masih kurang baik, dan ternyata semua aspek tersebut sesuai dengan dugaan semula. Temuan penelitian ini hampir sama dengan dugaan awal atau pra survei, walaupun peneliti menyimpulkan data awalnya dari data yang berdasarkan pada pengamatan kasat mata saja.

Setelah dilakukan pengamatan yang sistematis dan prosedural melalui penelitian dengan menggunakan metode ilmiah dimana pengukuran menggunakan instrumen yang sahih ternyata hasilnya lebih baik.

Hasil analisis data dan pengujian hipotesis menunjukkan bahwa ketiga hipotesis telah teruji secara empiris. Dari hasil analisi data menunjukkan bahwa Gaya kepemimpinan kepala sekolah dan Kepuasan kerja guru baik secara sendiri-sendiri maupun secara bersama-sama memiliki hubungan yang berarti dengan Etos kerja guru SD Negeri di Padang Panjang. Adapun besarnya hubungan antara Gaya kepemimpinan kepala sekolah dengan Etos kerja guru SD Negeri di Padang Panjang adalah 27,1\%, hubungan antara Kepuasan kerja guru dengan Etos kerja guru SD Negeri di Padang Panjang adalah 26,2 $\%$, dan apabila secara bersama-sama antara Gaya kepemimpinan kepala sekolah dan Kepuasan kerja guru dengan Etos kerja guru SD Negeri di Padang Panjang secara secara bersama - sama memiliki hubungan yang berarti yakni sebesar 39,5\%Hubungan Gaya Kepemimpinan kepala sekolah dengan Etos Kerja guru SD Negeri di Padang Panjang. Setelah dilakukan pengkajian mendalam melalui proses analisis di atas, maka diyakini bahwa hipotesis penelitian yang menyatakan "Gaya Kepemimpinan kepala sekolah berhubungan dengan Etos Kerja guru SD Negeri di Padang Panjang" dapat diterima dan telah teruji pada tarap kepercayaan 95 $\%$. Selanjutnya dapat diinterprentasikan bahwa Gaya kepemimpinan kepala sekolah memiliki hubungan sangat signifikan dengan Etos kerja guru SD Negeri di Padang Panjang, hal ini menunjukkan bahwa keberhasilan Etos kerja guru ditentukan oleh gaya kepemimpinan kepala sekolah.

Kepala sekolah dalam mengambil keputusan, Membagi tugas kepada guru, Menghargai guru dan Membimbing / mengarahkan guru ternyata berhugungan dengan etos kerja guru, dimana setiap kepala sekolah mengambil langkah-langkah 
yang menyangkut dengan etos kerja guru selalu berhungan dengan bagaimana guruguru memandang pekerjaannya sebagai guru, yang akhirnya berhubungan dengan bagaimana guru itu akan melaksanakan kegiatannya sebagai seorang guru, seperti bagaimana guru itu menerapkan disiplin, bertanggung jawab, kerja keras, kretaifitas dan rasional terhadap pekerjaannya.

Hubungan Kepuasan kerja guru dengan Etos Kerja guru SD Negeri di Padang Panjang. Anoraga (1998 :29) menyatakan, bahwa etos kerja guru adalah suatu pandangan dan sikap suatu bangsa atau suatu umat terhadap kerja. Jika pandangan dan sikap, melihat kerja sebagai suatu yang luhur untuk eksistensi manusia maka etos kerja guru itu akan tinggi, begitupun jika melihat kerja sebagai suatu hal tidak berarti dalam kehidupan, pandangan dan sikap, manusia terhadap kerja, maka etos kerja guru dengan sendirinya menjadi rendah.

Seseorangyang mempunyai kemampuan/ kesanggupan yang tinggi akan mempunyai etos kerja guru yang tinggi pula. Kerena dengan kemampuan yang dimilikinya ia akan dapat menyelesaikan tugasnya sendiri tanpa harus minta bantuan atau petunjuk orang lain. Motivasi atau dorongan akan memberikan energi, mendorong kegiatan atau gerakan dan mengarahkan atau menyalurkan prilaku kearah mencapai kebutuhan yang memberi kepuasan atau mengurangi ketidak seimbangan. Dengan motivasi atau dorongan yang dipunyai akan membuat seseorang untuk berbuat dalam melaksanakan tugas dan akan mendorong sikap keterbukaan yang meningkatkan etos kerja guru. Dengan demikian dapat dikatakan bahwa etos kerja guru akan berhubungan dengan kepuasan kerja guru dalam melaksanakan pekerjaan pada suatu sekolah.

Menurut Ali Imran ( 125 ) Kepuasan kerja adalah “... jika sumber-sumber kepuasan kerja terpenuhi, maka seseorang merasakan tingginya kepuasan kerja. Sebaliknya jika sumber-sumber kepuasan kerja tidak terpenuhi, maka ia akan merasakan kepuasan kerja itu rendah". Dalam hal ini sumber - sumber kepuasan kerja yang telah ditentukan indikatornya di landasan teoritis adalah pendapatan, prestasi kerja, penghargaan dilingkungan organisasi, suasana lingkungan kerja, dan pekerjaan yang menantang. Dalam analisis data tergambar bahwa tingkat pencapaian responden terhadap variabel kepuasan kerja adalah kurang.

Sesuai dengan hipotesis yang di nyatakan “Kepuasan kerja guru berhubungan yang signifikan dengan Etos kerja guru SD Negeri di Padang Panjang” dapat diterima dan telah teruji pada tarap kepercayaan $95 \%$. Selanjutnya dapat diinterprentasikan bahwa Kepuasan kerja guru memiliki hubungan sangat signifikan dengan Etos kerja guru SD Negeri di Padang Panjang sebesar 26,2 $\%$. Hal ini menunjukkan bahwa 26,2 \% 
keberhasilan Etos kerja guru ditentukan oleh Kepuasan kerja guru.

Hubungan Gaya Kepemimpinan kepala sekolah dan Kepuasan Kerja guru dengan Etos Kerja guru SD Negeri di Padang Panjang

Hubungan gaya kepemimpinan kepala sakolah dan kepuasan kerja guru dengan etos kerja guru sebesar 39,5\%. Hal ini menunjukkan bahwa 39,5\% Etos kerja guru SD Negeri di Padang Panjang berhubungan dengan gaya kepemimpinan kepala sekolah dan Kepuasan kerja guru. Dengan kata lain secara simultan kedua faktor tersebut mempunyai hubungan dengan Etos kerja guru SD Negeri di Padang Panjang.

Dengan menggunakan analisis korelasi dan regresi berganda antara variabel bebas Kepemimpinan kepala sekolah (X1) dan kepuasan kerja guru $\left(X_{2}\right)$ dengan variabel terikat etos kerja guru $(\mathrm{Y})$ dapat diketahui besarnya koefisien korelasi Ry.1.2 $=0.629$ dan koefisien determinasi sebesar $\mathrm{R}^{2} \mathrm{y} \cdot 1.2$ $=0.395$. Dapat disimpulkan bahwa 39,5 $\%$ variasi yang terjadi pada variabel etos kerja guru disebabkan oleh kedua variabel bebas Gaya Kepemimpinan kepala sekolah dan kepuasan kerja guru, sementara sisanya $60,5 \%$ disebabkan oleh faktor lain di luar variabel yang diteliti.

\section{PENUTUP}

Berdasarkan hasil penelitian dan analisis tentang Etos kerja guru yang diperoleh dari data penelitian berkaitan dengan hubungan
Gaya kepemimpinan kepala sekolah dan kepuasan kerja guru disimpulkan bahwa:

Gaya kepemimpinan kepala sekolah berhubungan yang signifikan dengan etos kerja guru SD Negeri di Padang Panjang sebesar $27,1 \%$. Ini berarti bahwa gaya kepemimpinan kepala sekolah yang baik memberikan dampak kepada etos kerja guru.

Kepuasan kerja guru SD Negeri di Padang Panjang berhubungan yang signifikan dengan etos kerja guru SD Negeri di Padang Panjang sebesar 26,2\%. Ini berarti bahwa Kepuasan kerja guru yang baik memberikan dampak kepada etos kerja guru SD Negeri di Padang Panjang.

Gaya kepemimpinan kepala sekolah dan kepuasan kerja guru secara bersama - sama ( simultan) berhubungan yang signifikan dengan Etos kerja guru SD Negeri di Padang Panjang sebesar 39,5\%. Hal ini menjelaskan bahwa untuk meningkatkan etos kerja guru dapat dilakukan melalui peningkatan kepuasan kerja guru bersamaan dengan perbaikan gaya kepemimpinan kepala sekolah guru SD Negeri di padang Panjang.

\section{KEPUSTAKAAN ACUAN}

Abdur Rahman an-Nahlawi, Ushulut Tarbiyah Al-Islamiyah fil Baiti Wal Madrasah Wal Mujtama, Terj: Shihabuddin (Jakarta : Gema Insani, 1995

A. Mukti ali, Beberapa Persoalan Agama Dewasa Ini, (Jakarta: Rajawali Press, 1987) 
Al-Gazali, al-Munkiz min al-Dahal, Beirut: Imran, Ali . Pembinaan guru di Indonesia, Dar al-Andalus, 1967 hal. 215

Anaroga, Pandji, dan Sri Suyati . Psikologi Nurcholis Majid, Islam Agama Kemanusiaan, kerja. Jakarta: Rineka cipta,1998 (Jakarta: Pramadina, 1995)

Bukhori Mokhtar, Pendidikan Dalam Zaini Sjahminan, Kuliyah Akidah Pembangunan, (Yogya Karta: Tiara Islam, (Surabaya: Al-Ikhlas, 1983) Wacana, 1994) 